\title{
The future of ERCP
}

\section{(ㅇ) $\circledast$}

Author

Richard A. Kozarek

Institutions

Digestive Disease Institute, Virginia Mason Medical Center, Seattle, Washington, United States

submitted 23.12.2016

accepted after revision $\quad 30.12 .2016$
Bibliography

DOI http://dx.doi.org/10.1055/s-0043-101697 |

Endoscopy International Open 2017; 05: E272-E274

(c) Georg Thieme Verlag KG Stuttgart · New York

ISSN 2364-3722

Corresponding author

Richard A. Kozarek, MD, Digestive Disease Institute, Virginia Mason

Medical Center, 1100 Ninth Avenue, Seattle, Washington, United

States

Phone: +1-206-223-6934

Fax: +1-206-223-6379

gasrak@vmmc.org
In the current issue of Endoscopy International Open, Ahmed, et al. discuss trends for utilization of endoscopic retrograde cholangio-pancreatography in the United States over the years 2002 to 2013 [1]. Not surprising has been a shift from diagnostic to therapeutic ERCP and an accompanying fall in total procedures in the years between 2011 and 2013. What this manuscript fails to define, however, is that the vast majority of ERCPs in the United States have morphed from inpatient to outpatient procedures. As such, the 37,400 procedures recorded and reported in the current paper annually are dwarfed by the total ERCPs recorded annually in the United States (estimated> 450,000) [2].

What does the manuscript tell us relative to inpatient trends? For one, the number of inpatient ERCPs indeed seems to have declined. In a previous study using the Nationwide Inpatient Sample Database (NIS) delineating ERCPs in hospitalized patients, Jamal et al. reported 402,343 patients undergoing an ERCP from 1998 to 2002, approximately 100,000 patients yearly compared to 37,400 yearly in the current study [3]. Moreover, during the earlier reporting period, the age-adjusted ERCP rate increased 3-fold between 1988 and 1996 from 25.66 to 74.95 per 100,000

In the current publication, the rate of increase approximated $12 \%$. Not surprisingly, there was a significant decrease in diagnostic procedures by $57 \%$ and a concomitant increase in therapeutic procedures by $37 \%$. The reasons, of course, are obvious and include improved noninvasive imaging (computed tomography and magnetic resonance imaging/magnetic resonance cholangiopancreatography), and the predominant role endoscopic ultrasound (EUS) has come to play in defining pancreaticobiliary lesions because of its relative safety and its superiority over ERCP in tissue acquisition [4-8]. Moreover, the rate of growth of therapeutic procedures has been blunted not only by the ability of EUS to access and apply therapy to the pancreas, bile duct, and gallbladder [9-13] but also as a conse- quence of studies showing no benefit for ERCP in select situations. As such, we no longer routinely undertake biliary drainage in jaundiced patients undergoing pancreatic surgery for malignancy [14]. Likewise, the EPISOD study has definitively shown us that there is no role for either ERCP or manometry in patients with type III Sphincter of Oddi dysfunction [15].

When Thierry Ponchon, the editor-in-chief of Endoscopy International Open, asked me to review the article by Ahmed discussed above, he also asked me to address the future of ERCP. However, the future is not monolithic and recent publications on ERCP developments in China demonstrate rapid growth in procedural volume, training, and outcomes that Western countries had historically reported [16]. On the other hand, as someone who has been doing ERCPs for the past 40 years, both in the West as well as the East, there are several simultaneous changes in practice patterns that I will reiterate:

1. ERCP has evolved primarily into an outpatient procedure with selective post-procedure admission, usually for less than 24 hours.

2. Additional training beyond that obtained in a conventional gastroenterology fellowship will be increasingly mandated and at a minimum, complex ERCPs referred to a Center of Excellence/tertiary care institution.

3. Endoscopists performing ERCP should also be skilled in EUS. I once referred to these as the salt and pepper shakers of pancreatobiliary disease although knife and fork imagery is probably more apropos. As an individual who trained long before the introduction of EUS, I nevertheless believe that the 2 skillsets are complementary and that practicing ERCP alone limits both new diagnostic and therapeutic options and may result in overutilization of one of the higher-risk procedures that we do in therapeutic endoscopy [17-25].

What else might the future bring? Certainly continued attempts, both mechanical and pharmacologic, to decrease the 
risk of procedural pancreatitis, much like we are currently doing with peri-procedural nonsteroidal anti-inflammatory drugs and small-diameter pancreatic duct stent placement [26-30]. The design and reprocessing of duodenoscopes that do not put our patients at risk of cross contamination and iatrogenic infections will also continue to take center stage for the foreseeable future [31-34].

In the initial edition of our ERCP text, the preface was entitled "ERCP Past, Present, and Future." At that time the editors discussed routine cholangioscopy, the potential injection of litholytic agents into the pancreas for chronic calcific pancreatitis, and directed infusion of chemotherapeutic or immunomodulatory agents into the pancreaticobiliary tree as potential future scenarios [35]. However, we also said that "the check is in the mail," and as such, it may or may not ever arrive. Its future will depend on parallel advancements in other imaging and laboratory advancements as well as breakthrough technology or techniques by other disciplines including interventional radiology and minimally invasive surgery.

In the third edition of ERCP currently in press, McHenry and Lehman in their chapter, "Approaching 50 Years: The History of ERCP," speculate that hands-free manipulation of a duodenoscope comparable to robotic-assisted surgery may be a future scenario, and that "studies of pancreatic juice may provide predictors of recurrent pancreatitis, pancreatic cancer risk, and response to chemotherapy" [36]. Comparable to our previous preface, the check is still in the mail, and the current author waits impatiently for delivery.

\section{Competing interests}

None

\section{References}

[1] Ahmed M, Kanotra R, Savani G et al. Utilization trends of inpatient endoscopic retrograde cholangiopancreatography (ERCP): A crosssectional US experience. Endosc Int Open 2017; 05: 261 - 271

[2] NIH Consens State Sci Statements. NIH state-of-the-science statement on endoscopic retrograde cholangiopancreatography (ERCP) for diagnosis and therapy. 2002; 19: 1-26

[3] Mazen Jamal M, Yoon E], Saadi A et al. Trends in the utilization of endoscopic retrograde cholangiopancreatography (ERCP) in the United States. Am J Gastroenterol 2007; 102: 966- 975

[4] Badger WR, Borgert A], Kallies Kj et al. Utility of MRCP in clinical decision making of suspected choledocholithiasis: An institutional analysis and literature review. Am J Surg 01.12 2016: DOI: 10.1016/j. amjsurg.2016.10.025 [Epub ahead of print]

[5] Sandrasegaran K, Tahir B, Barad U et al. The value of secretin-enhanced MRCP in patients with recurrent acute pancreatitis. AJR Am J Roentgenol 08.11 2016: 1 - 7

[6] Bhat M, Romagnuolo J, da Silveira E et al. Randomised clinical trial: MRCP-first vs. ERCP-first approach in patients with suspected biliary obstruction due to bile duct stones. Aliment Pharmacol Ther 2013; 38: $1045-1053$
[7] Oh SY, Irani S, Kozarek RA. What are the current and potential future roles for endoscopic ultrasound in the treatment of pancreatic cancer? World J Gastrointest Endosc 2016; 8: 319-329

[8] Heinzos HS, Kammerer S, Rammes C et al. Comparative analysis of ERCP, IDUS, EUS and CT in predicting malignant bile duct strictures. World J Gastroenterol 2014; 20: 10495 - 10503

[9] Poincloux L, Rouquette O, Buc E et al. Endoscopic ultrasound-guided biliary drainage after failed ERCP: cumulative experience of 101 procedures at a single center. Endoscopy 2015; 47: $794-801$

[10] Khashab MA, Messallam AA, Penas I et al. International multicenter comparative trial of transluminal EUS-guided biliary drainage via hepatogastrostomy vs. choledochoduodenostomy approaches. Endosc Int Open 2016; 4: E175-181

[11] Gornals JB, Esteban JM, Guarner-Argente C et al. Endoscopic ultrasound and endoscopic retrograde cholangiopancreatography: Can they be successfully combined? Gastroenterol Hepatol 2016; 39: $627-641$

[12] Kumbhari V, Penas I, Tieu AH et al. Interventional EUS using a flexible 19-gauge needle: An international multicenter experience in 162 patients. Dig Dis Sci 2016; 61: $3552-3559$

[13] Law R, Baron TH. Endoscopic ultrasound-guided biliary interventions: An update on recent developments. Curr Opin Gastroenterol 2016; 32: $232-237$

[14] Baron T, Kozarek RA. Preoperative biliary stents in pancreatic cancer proceed with caution. (Editorial) N Engl J Med 2010; 362: 170-172

[15] Cotton P, Durkalski V, Romagnuolo J et al. Effect of endoscopic sphincterotomy for suspected sphincter of Oddi dysfunction on painrelated disability following cholecystectomy. The EPISOD randomized clinical trial. JAMA 2014; 311: 2101-2109 (Also published in abstract form.)

[16] Liao Z, Hu LH, Xin L et al. ERCP service in China: results from a national survey. Gastrointest Endosc 2013; 77: 39-46

[17] Tybert A, Desai AP, Kumta NA et al. EUS-guided biliary drainage after failed ERCP: A novel algorithm individualized based on patient anatomy. Gastrointest Endosc 2016; 84: 941 - 946

[18] Sharaiha RZ, Kumta NA, Desai AP et al. Endoscopic ultrasound-guided biliary drainage versus percutaneous transhepatic biliary drainage: predictors of successful outcome in patients who fail endoscopic retrograde cholangiopancreatography. Surg Endosc 2016; 30: 5500 5505

[19] Khashab MA, Van der Merwe S, Kunda R et al. Prospective international multicenter study on endoscopic ultrasound-guided biliary drainage for patients with malignant distal biliary obstruction after failed endoscopic retrograde cholangiopancreatography. Endosc Int Open 2016; 4: E487-496

[20] Patil R, Ona MA, Papafragkakis C et al. Endoscopic ultrasound-guided placement of the lumen-apposing self-expandable metallic stent for gallbladder drainage: a promising technique. Ann Gastroenterol 2016; 29: $162-167$

[21] Patil R, Ona MA, Papafragkakis C et al. Endoscopic ultrasound-guided placement of AXIOS stent for drainage of pancreatic fluid collections. Ann Gastroenterol 2016; 29: 168 -173

[22] Shah RJ, Shah JN, Waxman I et al. Safety and efficacy of endoscopic ultrasound-guided drainage of pancreatic fluid collections with lumen-apposing covered self-expanding metal stents. Clin Gastroenterol Hepatol 2015; 13: $747-752$

[23] Kawakubo K, Kawakami H, Kuwatani M et al. Recent advances in endoscopic ultrasonography-guided biliary interventions. World J Gastroenterol 2015; 21: 9494-9502

[24] French JB, Coe AW, Pawa R. Endoscopic ultrasound-guided choledochoduodenostomy with a lumen-apposing, self-expandable fully covered metal stent for palliative biliary drainage. Clin J Gastroenterol 2015; 9: 79-85 
[25] Hara K, Yamao K, Mizuno N et al. Endoscopic ultrasonography-guided biliary drainage: Who, when, which, and how? World J Gastroenterol 2016; 22: $1297-1303$

[26] Patil S, Pandey V, Pandev N et al. Role of rectal diclofenac suppository for prevention and its impact on severity of post-endoscopic retrograde cholangiopancreatography pancreatitis in high-risk patients. Gastroenterology Res 2016; 9: 47 - 52

[27] Mok SR, Ho HC, Shah P et al. Lactated Ringer's solution in combination with rectal indomethacin for prevention of post-ERCP pancreatitis and readmission: A prospective randomized, double-blinded, placebo-controlled trial. Gastrointest Endosc 2016: DOI: 10.1016/j. gie.2016.10.033 [Epub ahead of print]

[28] Vadala di Prampero SF, Faleschini G et al. Endoscopic and pharmacological treatment for prophylaxis against post endoscopic retrograde cholangiopancreatography pancreatitis: a meta-analysis and systematic review. Eur J Gastroenterol Hepatol 2016; 28: 1415 - 1424

[29] Smeets XJ, da Costa DW, Besselink MG et al. Systematic review: periprocedural hydration in the prevention of post-ERCP pancreatitis. Aliment Pharmacol Ther 2016; 44: 541 - 553

[30] Kubilun NM, Adams MA, Akshintala VS et al. Evaluation of pharmacologic prevention of pancreatitis after endoscopic retrograde cholan- giopancreatography: A systematic review. Clin Gastroenterol Hepatol 2015; 13: 1231 - 1239

[31] Rutala WA, Weber DJ. Outbreaks of carbapenem-resistant Enterobacteriaceae infections associated with duodenoscopes: What can we do to prevent infections? Am J Infect Control 2016; 44: (Suppl. 05): e47 e51

[32] Jung M, Beilenhoff U. Hygiene: The looming Achilles heel in endoscopy. Visc Med 2016; 32: $21-28$

[33] Kim S, Muthusamy VR. Current practice of duodenoscope reprocessing. Curr Gastroenterol Rep 2016; 18: 54

[34] Higa JT, Gluck M, Ross AS. Duodenoscope-associated bacterial infections: A review and update. Curr Treat Options Gastroenterol 2016; 14: $185-193$

[35] Baron TH, Kozarek RA, Carr-Locke DL (ed.) Preface in ERCP. Philadelphia: Saunders-Elsevier; 2008

[36] McHenry L, Lehman G. History of ERCP, in Baron TH, Kozarek RA, CarrLocke DL (eds.), ERCP 3rd edition. Philadelphia: Saunders-Elsevier; 2017: in press. 